\title{
Correction to: Hardened properties and durability of large- scale 3D printed cement-based materials
}

\author{
Yu Zhang • Yunsheng Zhang • Lin Yang • Guojian Liu • Yidong Chen • \\ Shiwei Yu $\cdot$ Hongjian Du
}

Accepted: 15 February 2022/Published online: 1 March 2022

(C) The Author(s) 2022

Correction to: Materials and Structures (2021) 54:45

https://doi.org/10.1617/s11527-021-01632-x

The article "Hardened properties and durability of large-scale 3D printed cement-based materials", written by $\mathrm{Yu}$ Zhang, Yunsheng Zhang, Lin Yang, Guojian Liu, Yidong Chen, Shiwei Yu and Hongjian $\mathrm{Du}$, was originally published Online without Open Access. After publication in volume 54, issue 1, article 45 the author decided to opt for Open Choice and to

The original article can be found online at https:// doi.org/10.1617/s11527-021-01632-x.

Y. Zhang · Y. Zhang $(\bowtie) \cdot$ Y. Chen

School of Materials Science and Engineering, Southeast University, Nanjing, China

e-mail: zhangys279@163.com

Y. Zhang

e-mail: zygwj88@yeah.net

Y. Zhang $\cdot$ Y. Zhang $\cdot$ Y. Chen

Collaborative Innovation Center for Advanced Civil

Engineering Materials, Nanjing 211189, China

Y. Zhang

School of Civil Engineering, Lanzhou University of Technology, Lanzhou 730050, China

L. Yang

School of Water Conservancy Engineering, Zhengzhou University, Zhengzhou 450001, China make the article an Open Access publication. Therefore, the copyright of the article has been changed to (C) The Author(s) 2021 and the article is forthwith distributed under the terms of the Creative Commons Attribution 4.0 International License, which permits use, sharing, adaptation, distribution and reproduction in any medium or format, as long as you give appropriate credit to the original author(s) and the source, provide a link to the Creative Commons licence, and indicate if changes were made. The images or other third party material in this article are included in the article's Creative Commons licence, unless indicated otherwise in a credit line to the

G. Liu

School of Civil Engineering, Suzhou University of Science and Technology, Suzhou 215011, China

$\mathrm{S} . \mathrm{Yu}$

Centre for Smart Infrastructure and Digital Construction, Swinburne University of Technology, Hawthorn, VIC 3122, Australia

H. Du ( $\bowtie)$

Department of Civil and Environmental Engineering, National University of Singapore, Singapore 117576, Singapore e-mail: ceedhj@nus.edu.sg 
material. If material is not included in the article's Creative Commons licence and your intended use is not permitted by statutory regulation or exceeds the permitted use, you will need to obtain permission directly from the copyright holder. To view a copy of this licence, visit http://creativecommons.org/ licenses/by/4.0.

Open Access This article is licensed under a Creative Commons Attribution 4.0 International License, which permits use, sharing, adaptation, distribution and reproduction in any medium or format, as long as you give appropriate credit to the original author(s) and the source, provide a link to the Creative Commons licence, and indicate if changes were made. The images or other third party material in this article are included in the article's Creative Commons licence, unless indicated otherwise in a credit line to the material. If material is not included in the article's Creative Commons licence and your intended use is not permitted by statutory regulation or exceeds the permitted use, you will need to obtain permission directly from the copyright holder. To view a copy of this licence, visit http://creativecommons.org/licenses/by/4.0/.

Publisher's Note Springer Nature remains neutral with regard to jurisdictional claims in published maps and institutional affiliations. 